\title{
A Comprehensive Study of Surface Chemistry for Application to Engine $\mathrm{NO}_{x}$ Aftertreatment
}

S. Aceves, C. Mundy, W. Pitz, M. Havstad, T. Piggott, W. Kuo

February 2, 2004

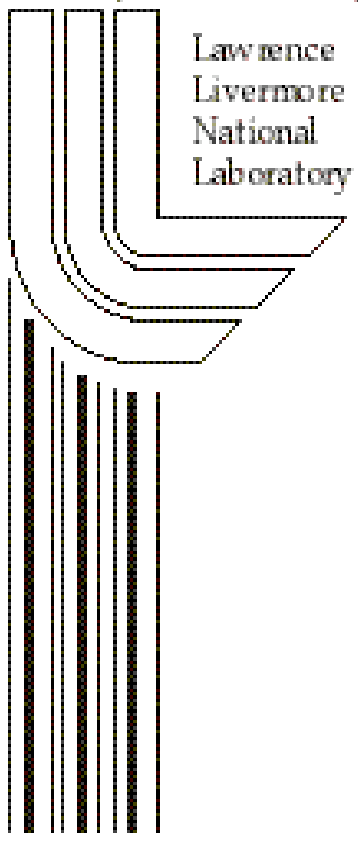




\section{DISCLAIMER}

This document was prepared as an account of work sponsored by an agency of the United States Government. Neither the United States Government nor the University of California nor any of their employees, makes any warranty, express or implied, or assumes any legal liability or responsibility for the accuracy, completeness, or usefulness of any information, apparatus, product, or process disclosed, or represents that its use would not infringe privately owned rights. Reference herein to any specific commercial product, process, or service by trade name, trademark, manufacturer, or otherwise, does not necessarily constitute or imply its endorsement, recommendation, or favoring by the United States Government or the University of California. The views and opinions of authors expressed herein do not necessarily state or reflect those of the United States Government or the University of California, and shall not be used for advertising or product endorsement purposes.

This work was performed under the auspices of the U. S. Department of Energy by the University of California, Lawrence Livermore National Laboratory under Contract No. W-7405-Eng-48.

This report has been reproduced directly from the best available copy.

Available electronically at http://www.doc.gov/bridge

Available for a processing fee to U.S. Department of Energy

And its contractors in paper from

U.S. Department of Energy

Office of Scientific and Technical Information

P.O. Box 62

Oak Ridge, TN 37831-0062

Telephone: (865) 576-8401

Facsimile: (865) 576-5728

E-mail: reports@adonis.osti.gov

Available for the sale to the public from

U.S. Department of Commerce

National Technical Information Service

5285 Port Royal Road

Springfield, VA 22161

Telephone: (800) 553-6847

Facsimile: (703) 605-6900

E-mail: orders@ntis.fedworld.gov

Online ordering: http:/ / www.ntis.gov/ordering.htm

\section{OR}

Lawrence Livermore National Laboratory

Technical Information Department's Digital Library

http:/ / www.llnl.gov/tid/Library.html 


\title{
A Comprehensive Study of Surface Chemistry for Application to Engine $\mathrm{NO}_{\mathrm{x}}$ Aftertreatment
}

\author{
Salvador Aceves (PI), Chris Mundy, William Pitz, Mark Havstad, \\ Tom Piggott (Ph.D. Student), Will Kuo (post-doc) \\ Lawrence Livermore National Laboratory \\ 422 0864, saceves@llnl.gov
}

\section{Problem Definition:}

This work focuses on developing a scientific understanding of the processes associated with $\mathrm{NO}_{\mathrm{x}}$ trap operation. $\mathrm{NO}_{\mathrm{x}}$ traps are the most advanced technology for achieving future emissions standards with diesel engines. Successful development of $\mathrm{NO}_{\mathrm{x}}$ traps will allow widespread use of diesel engines in light-duty vehicles, reducing oil imports by as much as $60 \%$.

Diesel engines have a high efficiency and low maintenance that makes them the ideal choice for transportation applications. Use of diesel engines in all light-duty vehicles would reduce oil consumption in the USA by $30 \%$ and oil imports by $60 \%$, considerably improving our energy security. For heavy trucks, there is no viable alternative to diesel engines. Only diesel engines can provide the necessary high efficiency and long life. These benefits are offset by high emission of pollutants. Diesel engines have high emissions of $\mathrm{NO}_{\mathrm{x}}$ and particulate matter. Over the last 20 years, EPA has been reducing allowable emissions from diesel engines, and $\mathrm{NO}_{\mathrm{x}}$ emissions are scheduled to be cut by a factor of 10 over the next 7 years (see Figure 1). The target $\mathrm{NO}_{\mathrm{x}}$ emissions for year 2010 is $0.20 \mathrm{~g} / \mathrm{hp}$-hr. This value is well below $1 \mathrm{~g} / \mathrm{hp}$-hr, which has been identified by one of the authors (Pitz [1]) as the minimum possible $\mathrm{NO}_{\mathrm{x}}$ emissions that can be obtained in a diesel engine with satisfactory combustion and without exhaust aftertreatment. An $80 \%$ efficient aftertreatment system is therefore necessary for achieving the $2010 \mathrm{NO}_{\mathrm{x}}$ emissions regulation. Achieving this level of diesel aftertreatment efficiency is a daunting task, and one that will require a strong research effort.

\section{Purpose:}

Manufacturing diesel aftertreatment systems with $80 \%$ efficiency for model year 2010 is an extremely difficult task. Our advanced analysis tools (computational chemistry linked with fluid mechanics and heat transfer) can be used to analyze and optimize $\mathrm{NO}_{\mathrm{x}}$ traps, which are the system of choice for diesel engine aftertreatment.

$\mathrm{NO}_{\mathrm{x}}$ adsorbing catalysts operate by adsorbing the $\mathrm{NO}_{\mathrm{x}}$ in the exhaust stream during regular engine operation. After a period of time ( 1 minute), the catalyst saturates and has to be regenerated. Regeneration is achieved by injecting a reductant (typically fuel, although hydrogen or ammonia can also be used) into the catalyst. The adsorbed $\mathrm{NO}_{\mathrm{x}}$ desorbs under rich conditions, and then reacts with the reductant, producing molecular nitrogen, water and carbon dioxide. The regeneration cycle typically lasts about 2 seconds. After the regeneration cycle, the catalyst is ready for a new adsorption cycle.

Intermittent regeneration of the catalytic surfaces is a complex process, and much of the basic science behind this process is not understood. Unsolved scientific problems include the development of chemical kinetic mechanisms for surface chemistry; the analysis of sulfur 
poisoning of the catalyst surfaces and the phenomenon of thermal aging of the catalyst materials. The adsorption and regeneration processes are dependent on gaseous flow rate, surface chemical kinetics and converter geometry. A comprehensive study of this process is of great importance to achieve the desired system efficiency for $\mathrm{NO}_{\mathrm{x}}$ reduction. The possibilities and future market opportunities are enormous.

This project supports the DOE mission by improving national security through reduced dependence on foreign oil. This work also provides an opportunity for enhancing our surface chemistry analysis capabilities, which have great applicability to missile reentry, fuel cells, and sensors for chemical warfare agents and explosives detection. In addition to this, we will help the US industry remain competitive and will help clean up the environment.

\section{Activities:}

We have used Molecular Dynamics to characterize the basic physics of $\mathrm{NO}_{\mathrm{x}}$ adsorption into barium oxide catalysts. We also have used thermo-fluids models for $\mathrm{NO}_{\mathrm{x}}$ traps to validate the molecular dynamics results and conduct detailed analysis and optimization of $\mathrm{NO}_{\mathrm{x}}$ traps. Deep scientific understanding of $\mathrm{NO}_{\mathrm{x}}$ trap processes will greatly assist manufacturers in meeting future emissions standards.

We have studied the microscopic mechanisms for trapping and release of $\mathrm{NO}_{\mathrm{x}}$ species on the surface of a barium oxide ( $\mathrm{BaO})$ catalyst. To this end, we use the Car-Parrinello molecular dynamics (CPMD) method in conjunction with Vanderbilt psuedopotentials. Calculations were performed on bulk $\mathrm{BaO}$ to test the validity of our parameters.

The next step is to perform calculations of bulk $\mathrm{BaO}$ surface at finite temperature. We found that the dispersion in the bands of $\mathrm{BaO}$ is quite large, and therefore many layers of the surface must be included in order to achieve a stable surface. We found this number of layers to be at least six. With this many layers included in the calculation the calculations become prohibitive. Thus, we also chose to adapt the frozen lattice approximation in order to achieve some early results. To this end, we ran two sets of calculations at 300K using CPMD. The first was a single $\mathrm{NO}_{2}$ molecule absorbed on a $\mathrm{BaO}$ surface. Our findings of this structure at $0 \mathrm{~K}$ are consistent with the findings of published data. The second calculation was two $\mathrm{NO}_{2}$ molecules on a $\mathrm{BaO}$ surface (Figure 2). Our findings at $0 \mathrm{~K}$ are consistent with computational studies of $\mathrm{NO}_{2}$ on $\mathrm{MgO}$ surfaces, namely the stable $0 \mathrm{~K}$ structure is a charge-separated species of $\mathrm{NO}_{2}{ }^{-}$and $\mathrm{NO}_{2}{ }^{+}$. $\mathrm{The}^{-}$ charge transfer between the two $\mathrm{NO}_{2}$ species allows them to be more strongly adsorbed to the $\mathrm{BaO}$ surface than neutral $\mathrm{NO}_{2}$ species. Also note in Figure 2 the interesting orientation of the $\mathrm{NO}_{2}$ species, one with the oxygen facing away from the $\mathrm{BaO}$ surface and the other with the oxygens facing towards the $\mathrm{BaO}$ surface. It is expected that if additional $\mathrm{NO}_{2}$ 's were added, the "one up, one down" orientation of the $\mathrm{NO}_{2}$ would be repeated. This is consistent with published computational findings for $\mathrm{NO}_{2}$ adsorption on $\mathrm{MgO}$ surfaces. However, no studies exist of the structures at $300 \mathrm{~K}$. Our initial results indicate that as the temperature is raised from $0 \mathrm{~K}$ to $300 \mathrm{~K}$ on $\mathrm{BaO}$, there is a charge transfer event back to the neutral $\mathrm{NO}_{2}$ moieties. If this result holds, then the kinetics of trapping at $300-500 \mathrm{~K}$ is leading to a very different picture than calculations at OK.

We have also developed a 1-dimensional thermal and fluid mechanics model of a $\mathrm{NO}_{\mathrm{x}}$ trap. The model currently uses generic chemical kinetics equations available from the literature. This 
model will be used to validate the mechanisms obtained from our analysis by performing comparisons with experimental results obtained at Caterpillar, PNNL and ORNL.

\section{Technical Outcome:}

The aim of this study is to underpin the microscopic mechanisms for trapping and release of $\mathrm{NO}_{\mathrm{x}}$ species on the surface of a barium oxide $(\mathrm{BaO})$ catalyst. The challenge of this problem from a computational point of view is many-fold. For one, there is little data in the literature on the electronic structure of bulk $\mathrm{BaO}$, so the choice of computational parameters (e.g. lattice constants, pseudopotetnials, and cut-offs) is basically unknown. The other issue pertains to the choice of adsorbing species, $\mathrm{NO}_{2} . \mathrm{NO}_{2}$ is a radical which means that one of the orbitals has occupation unity. Computationally speaking this requires that each electron be treated as a separate degree of freedom which then doubles the computational effort of treating the $\mathrm{BaO}$ surface from the start. There have been recent computational studies of $\mathrm{NO}_{\mathrm{x}}$ on $\mathrm{BaO}$ surfaces performed with density functional theory methods. In this investigation, the geometries of $\mathrm{NO}_{\mathrm{x}}$ moieties on the $\mathrm{BaO}$ surface were studied at $0 \mathrm{~K}$. There are many approximations that were made in this study that we would like to improve upon. First, since the catalysts operate at between $300-500 \mathrm{~K}$, we would like to understand the $\mathrm{NO}_{\mathrm{x}}$ moieties under these more realistic conditions. Second, the $\mathrm{BaO}$ lattice was not allowed to relax. Therefore, the precise nature of the how the phonon modes couple to the $\mathrm{NO}_{\mathrm{x}}$ will be unknown unless this restriction can be relaxed. As of mid-year we considered the use of Vanderbilt psuedopotentials in conjunction with CarParrinello molecular dynamics (CPMD) to investigate the structure of $\mathrm{BaO}$. The goal of this was to reduce the computational costs. As of mid-year we reached our goal of simulating a fully loaded surface of $\mathrm{BaO}$ with $\mathrm{NO}_{2}$ moiety at $500 \mathrm{~K}$, the operating temperature of a $\mathrm{NO}_{\mathrm{x}}$ trap in a working engine (see attached movies). Our conclusion from this pioneering study is that geometries obtained by studying the system at $0 \mathrm{~K}$ may not correspond to actual structures obtained at the working temperature in a diesel engine. There were two issues that still needed to be resolved. As of mid-year we wanted to stay with a more computationally tractable "frozen" lattice (keeping the $\mathrm{BaO}$ molecules fixed). In order to have confidence in our new results, we had to convince ourselves that the lattice does not play a significant role in the chemi/physisorption. The second issue was concerning the extent of a perfect $\mathrm{BaO}$ crystal representing an active $\mathrm{NO}_{\mathrm{x}}$ trap.

We have addressed both of these issues. First, we are now using norm-conserving pseudopotentials with a cut-off 100 Rydbergs and using the generalized gradient approximation for the exchange and correlation functional. This produced remarkable results for bulk and surface stucture of $\mathrm{BaO}$ (see Fig. 1). Using the tera-scale resources at LLNL, we are able to perform calculations on a $2 \times 2 \times 2$ unit cell, only fixing the bottom-most layer to the bulk value (as commonly performed) and allowing for full relaxation of the remaining degrees of freedom. The second issue pertains to the supporting medium. Recent experiments have isolated, through infra-red spectroscopy, the presence of $\mathrm{BaCO}_{3}$ in the witherite structure. This is not so surprising since $\mathrm{NO}_{\mathrm{x}}$ traps operate in $\mathrm{CO}_{2}$ rich environment. In order to see if the mechanisms of chemi/physi-sorption are similar to the $\mathrm{BaO}$, we choose to perform calculations at finite temperature using witherite as the $\mathrm{NO}_{\mathrm{x}}$ trap (see Fig. 2). The same psuedopotentials and exchange and correlation functionals were used as in the case of $\mathrm{BaO}$.

Future work will focus on corroborating our findings at finite temperature and documenting the electron transfer with Wannier function analysis. Once this has been achieved, and we can 
perform calculations to determine and compare the binding energies of a variety of $\mathrm{NO}_{\mathrm{x}}$ moieties on fully relaxed surfaces of $\mathrm{BaO}$ and $\mathrm{BaCO}_{3}$.

\section{Conclusions:}

This project focuses on the scientifically and technically important problem of analyzing and modeling $\mathrm{NO}_{\mathrm{x}}$ traps for diesel engine aftertreatment. We conducted an analysis based on a combination of analysis tools: a molecular analysis code for determining the basic reaction characteristics of the system and a fluid mechanics and heat transfer code to validate the results against experimental data. The work sheds new light on the processes that control the adsorption and desorption of $\mathrm{NO}_{\mathrm{x}}$ molecules on barium substrates, and will be of great practical utility for designing improved $\mathrm{NO}_{\mathrm{x}}$ traps.

\section{References:}

1. Flynn, P.F.; Hunter, G.L.; Farrell, L.; Durrett, R.P.; Akinyemi, O.; Westbrook, C.K.; Pitz, W.J.; Loye, A. O. Zur, "The inevitability of engine-out $\mathrm{NO}_{\mathrm{x}}$ emissions from spark-ignited and diesel engines," Proceedings of the Combustion Institute, V. 28, n 1, 2000, p 1211-1217.

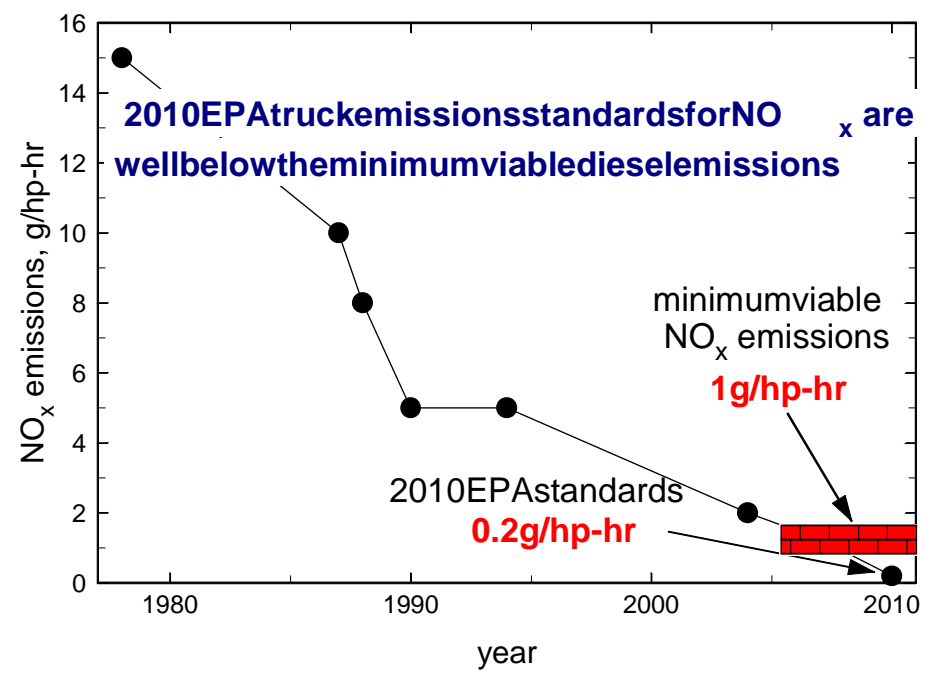

Figure 1. Evolution of NOx and PM emissions standards for heavy-duty diesel engines. The figure also shows the minimum $\mathrm{NO}_{\mathrm{x}}$ emissions that can be obtained from a diesel engine with no aftertreatment. 


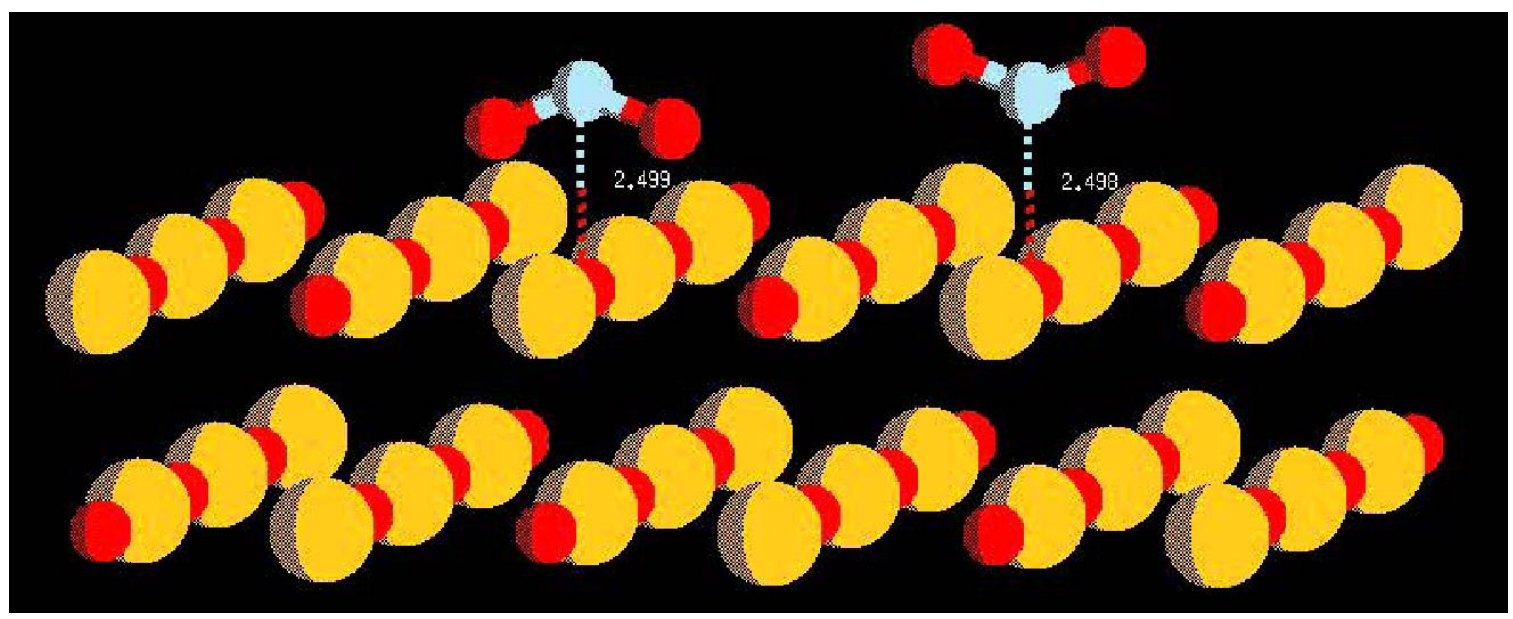

Figure 2. First-principles $\mathrm{CP}$ molecular dynamics simulation of $\mathrm{NO}_{2}$ storage on a Barium-oxide surface using the MCR cluster.

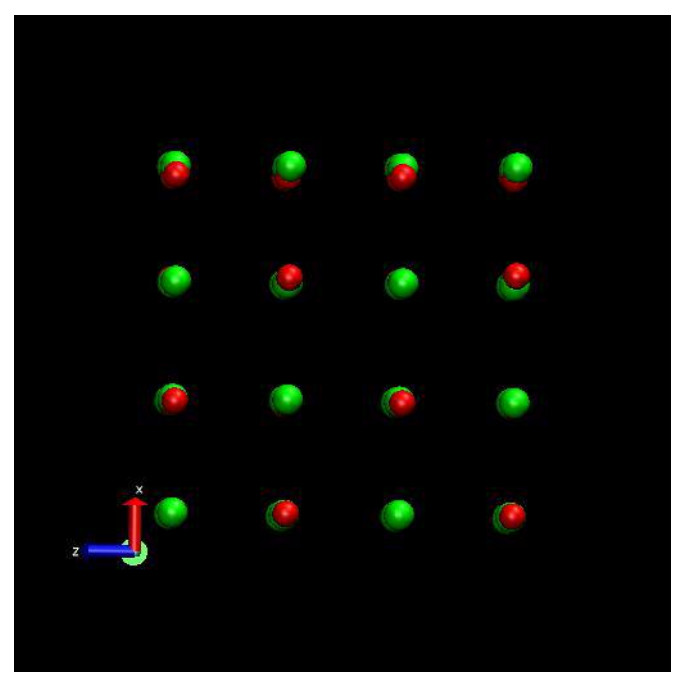

Figure 3. Relaxed surface of $\mathrm{BaO}$. The bottom layer is fixed. One can discern a slight relaxation of the oxygens in the topmost layer in conjunction with previous investigations. 


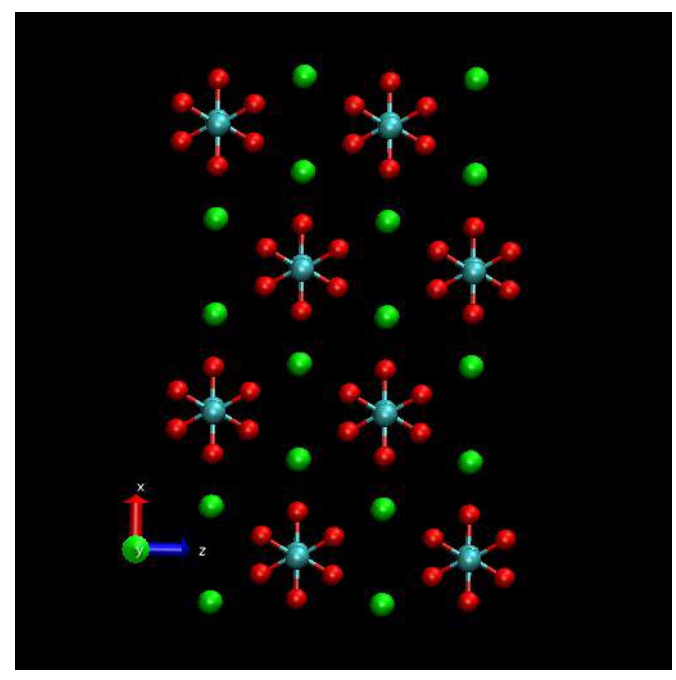

Figure 4. Relaxed $\mathrm{BaCO}_{3}$ surface in the witerite geometry. One can infer the possibilities for different chemistry to take place as compared to the $\mathrm{BaO}$ surface. 